\title{
Review
}

\section{Advances in the Noninvasive Diagnosis of Dry Eye Disease}

\author{
Luca Di Cello ${ }^{1,+}{ }^{\dagger}$, Marco Pellegrini ${ }^{2,3,4,+} \oplus$, Aldo Vagge ${ }^{1}\left(\mathbb{D}\right.$, Massimiliano Borselli ${ }^{5}$, Lorenzo Ferro Desideri ${ }^{1}$, \\ Vincenzo Scorcia ${ }^{5}{ }^{\circledR}$, Carlo E. Traverso ${ }^{1}$ and Giuseppe Giannaccare ${ }^{5, *}$
}

1 IRCCS Ospedale Policlinico San Martino, University Eye Clinic of Genoa, 16132 Genoa, Italy; luca.di.cello88@gmail.com (L.D.C.); aldo.vagge@gmail.com (A.V.); lorenzoferrodes@gmail.com (L.F.D.); mc8620@mclink.it (C.E.T.)

2 Department of Ophthalmology, Ospedali Privati Forlì “Villa Igea”, 47122 Forlì, Italy; marco.pellegrini@hotmail.it

3 Istituto Internazionale per La Ricerca e Formazione in Oftalmologia (IRFO), 47122 Forlì, Italy

4 Department of Translational Medicine, University of Ferrara, 44121 Ferrara, Italy

5 Department of Ophthalmology, University Magna Graecia of Catanzaro, 88100 Catanzaro, Italy; mborselli93@gmail.com (M.B.); vscorcia@libero.it (V.S.)

* Correspondence: giuseppe.giannaccare@unicz.it; Tel./Fax: +39-096-1364-7041

+ These authors contributed equally to the work.

Citation: Di Cello, L.; Pellegrini, M.; Vagge, A.; Borselli, M.; Ferro Desideri, L.; Scorcia, V.; Traverso, C.E.;

Giannaccare, G. Advances in the Noninvasive Diagnosis of Dry Eye Disease. Appl. Sci. 2021, 11, 10384 https://doi.org/10.3390/app112110384

Academic Editors: Itziar Fernández Martínez and Alberto López-Miguel

Received: 3 October 2021

Accepted: 29 October 2021

Published: 5 November 2021

Publisher's Note: MDPI stays neutral with regard to jurisdictional claims in published maps and institutional affiliations.

Copyright: $\odot 2021$ by the authors. Licensee MDPI, Basel, Switzerland. This article is an open access article distributed under the terms and conditions of the Creative Commons Attribution (CC BY) license (https:// creativecommons.org/licenses/by/ $4.0 /)$.

\begin{abstract}
Dry eye disease (DED) is a multifactorial disease that represents one of the most common ophthalmologic conditions encountered in everyday clinical practice. Traditional diagnostic tests for DED, such as subjective questionnaires, tear film break-up time and the Schirmer test, are often associated with poor reproducibility and reliability, which make the diagnosis, follow-up, and management of the disease challenging. New advances in imaging technologies enable objective and reproducible measurements of DED parameters, thus making the diagnosis a multimodal imagingbased process. The aim of this review is to summarize all the current and emerging diagnostic tools available for the diagnosis and monitoring of DED, such as non-invasive tear breakup time, thermography, anterior segment optical coherence tomography, meibography, interferometry, in vivo confocal microscopy, and optical quality assessment. Although there is not a gold standard imaging technique, new multi-imaging-integrated devices are precious instruments to help clinicians to better cope with the diagnostic complexity of DED.
\end{abstract}

Keywords: dry eye; diagnosis; noninvasive diagnosis; advanced imaging; NIBUT

\section{Introduction}

Dry eye disease (DED) is one of the most common ophthalmologic conditions encountered in everyday clinical practice [1]. The 2017 report by the Tear Film and Ocular Surface Society (TFOS) Dry Eye Workshop (DEWS II) published the renewed definition of DED, which was defined as an ocular surface disorder in which multiple pathological events, including tear film instability, hyperosmolarity, inflammation and neurosensory abnormalities, lead to the loss of the homeostasis of the entire system [2]. Common symptoms of DED include, among others, irritation, redness, foreign body sensation, blurry vision, tearing, and sensitivity to light. It is a chronic condition that also represents an important economic burden for both patients and society [3].

Performing a suitable clinical diagnosis of DED can be challenging, as its signs and symptoms are often poorly correlated. Combinations of subjective symptoms evaluated by questionnaires, slit lamp examination and (non-)invasive diagnostic tests have been used to obtain the diagnosis. The TFOS DEWS II Diagnostic Methodology report identified a diagnostic algorithm for a stepwise analysis that includes, after triaging questions, the evaluation of symptoms and homeostasis markers (noninvasive or fluorescein break-up time, tear osmolarity and ocular surface staining) [4]. Nonetheless, the report acknowledged 
that no single gold standard test has yet been established, and that there is a need for new, reliable diagnostic biomarkers.

In recent years, a great number of imaging techniques and devices for the examination of the ocular surface have been developed and placed on the market (Table 1). These devices offer the advantage of providing automated results of the examined tests, thus avoiding observer bias; moreover, since most of these examinations are noninvasive, they do not alter the results of subsequent tests, representing useful screening tools for discriminating healthy subjects from patients affected by or at risk for DED. Finally, combining different techniques in a comprehensive ocular surface workup may increase sensitivity and specificity to diagnose the disease and monitor its course after specific treatments [5-7].

In this review, we summarize the current research available about the development and use of novel noninvasive diagnostic techniques for the diagnosis and follow-up of DED.

Table 1. Multi-imaging-integrated devices and features.

\begin{tabular}{|c|c|c|c|c|c|}
\hline & IDRA & KERATOGRAPH & O.S.A. & LACRYDIAG & TEARCHECK \\
\hline N.I.B.U.T & $\begin{array}{l}\text { Automatic evaluation } \\
\text { of tear film break-up } \\
\text { time }\end{array}$ & $\begin{array}{l}\text { Automatic evaluation of } \\
\text { tear film break-up time } \\
\text { with infrared } \\
\text { illumination }\end{array}$ & $\begin{array}{c}\text { Automatic evaluation } \\
\text { of tear film } \\
\text { break-up time }\end{array}$ & $\begin{array}{c}\text { Automatic evaluation } \\
\text { of tear film } \\
\text { break-up time }\end{array}$ & $\begin{array}{c}\text { Automatic evaluation } \\
\text { of tear film } \\
\text { break-up time }\end{array}$ \\
\hline Meibography & $\begin{array}{l}\text { View of the presence } \\
\text { of abnormal gland } \\
\text { structures in a } \\
\text { high-resolution } \\
\text { 3D image }\end{array}$ & $\begin{array}{l}\text { Morphological changes in } \\
\text { the gland tissue are made } \\
\text { visible using the } \\
\text { Meibo-Scan and can be } \\
\text { classified with the } \\
\text { JENVIS Meibo } \\
\text { Grading Scales }\end{array}$ & $\begin{array}{l}\text { View of the presence } \\
\text { of abnormal gland } \\
\text { structures in a } \\
\text { high-resolution } \\
\text { 3D image }\end{array}$ & $\begin{array}{l}\text { Automatic detection } \\
\text { of meibomian glands } \\
\text { and automatic } \\
\text { calculation of the } \\
\text { percentage of loss }\end{array}$ & $\begin{array}{l}\text { Viewof the rate of } \\
\text { gland loss in } \%\end{array}$ \\
\hline Interferometry & $\begin{array}{c}\text { Automatic evaluation } \\
\text { of the lipid layer }\end{array}$ & $\begin{array}{l}\text { The thickness of the lipid } \\
\text { layer is automatically } \\
\text { assessed based on the } \\
\text { structure and color }\end{array}$ & $\begin{array}{c}\text { Manual evaluation of } \\
\text { the lipid layer }\end{array}$ & $\begin{array}{l}\text { Qualitative and } \\
\text { quantitative analysis } \\
\text { of the lipid layer } \\
\text { Evaluation of lipid } \\
\text { layer thickness based } \\
\text { on a grading scale }\end{array}$ & Not available \\
\hline Tear Meniscus & $\begin{array}{c}\text { Estimation of the tear } \\
\text { film quantity up to } \\
5 \text { values }\end{array}$ & $\begin{array}{l}\text { The height of the tear } \\
\text { meniscus can be precisely } \\
\text { measured with an } \\
\text { integrated ruler }\end{array}$ & $\begin{array}{l}\text { Estimation of the tear } \\
\text { film quantity up to } \\
\text { five values }\end{array}$ & $\begin{array}{c}\text { Measurement of tear } \\
\text { meniscus } \\
\text { height }(\mathrm{mm})\end{array}$ & $\begin{array}{c}\text { Calculate manually } \\
\text { the height of the tear } \\
\text { meniscus }\end{array}$ \\
\hline Bulbar Redness & $\begin{array}{l}\text { Comparison with all } \\
\text { international grading } \\
\text { scales (efron, } \\
\text { cclru, jenvis) }\end{array}$ & $\begin{array}{c}\text { The R-Scan automatically } \\
\text { detects the blood vessels } \\
\text { in the conjunctiva and } \\
\text { evaluates the degree } \\
\text { of redness }\end{array}$ & $\begin{array}{l}\text { Comparison with all } \\
\text { international grading } \\
\text { scales (efron, cclru, } \\
\text { jenvis) }\end{array}$ & Not available & Available \\
\hline
\end{tabular}

NIBUT = noninvasive break up time, LACRYDIAG (Quantel Medical), IDRA (Sbm Sistemi, Inc., Torino, Italy), OSA (Sbm Sistemi, Inc., Torino, Italy), KERATOGRAPH 5 M (Oculus Optikgeräte GmbH, Wetzlar, Germany), TEARCECK (NewTech s.p.a., MI, Italy).

\section{Noninvasive Tear Break-Up Time}

Pre-corneal film stability plays a critical role in the homeostasis of the ocular surface, and it is an important parameter to be considered for DED diagnosis [4,8]. In fact, the tear film is the first optical interface between the air and the ocular surface, and since there is a large difference in refractive index between the air and the tear, inhomogeneity in its structure has a major impact on the optical quality. In DED, there is a quantitative and/or qualitative tear deficiency that determines irregularities and/or the early break-up of the tear film $[9,10]$. In clinical practice, the most frequently employed test for the measurement of tear film stability is the fluorescein tear film breakup time (BUT), which is the interval time between the eyelid opening after a complete blink and the first break in the tear film. Since BUT requires the use of fluorescein, whose quantity and concentration can also affect the final measurement, noninvasive BUT (NIBUT) has become widely used in both clinical practice and research settings. DEWS II indicated that a cutoff value of NIBUT $\leq 10 \mathrm{~s}$ is an indicator for the diagnosis of DED, with a sensitivity of $82-84 \%$ and a 
specificity of 76-94\% [4]. There are several commercially available NIBUT systems, based on topographic or videokeratographic methods, which analyze the inter-blink changes of reflected placido mires. A change in the edges of the mires reflects compromised tear film integrity. Bandlitz et al. demonstrated that there is agreement and repeatability of measure between subjective and objective devices [11], while Lee et al. demonstrated that the agreement between the results extrapolated from two different instruments (Tomey RT-7000 Auto Refractor-Keratometer and Oculus Keratograph) was poor [12]. The Keratograph $5 \mathrm{M}$ (Oculus Optikgeräte GmbH, Wetzlar, Germany) allows the measure of quantitative values, such as the NIBUTf, which is the initial tear film breakup, whereas the NIBUTav represents the average of all tear film breakups occurring over the entire cornea. Both parameters have been reported to be correlated with Ocular Surface Disease Index (OSDI) score [13,14].

\section{Light Scatter}

Light scattering is a physical phenomenon in which light when hits a small object (a particle or a molecule) changes its direction. In human eyes, aberrations and light scattering are the main factors in the degradation of optical quality [15]. In DED, the loss of integrity of the tear film and the early exposure of the rough epithelium can lead to an increase in the ocular forward light scattering detected by C-Quant straylight meter (Oculus GmbH, Wetzlar, Germany). In DED eyes with superficial punctate keratopathy, there is also an increase in corneal backward light scattering from the anterior corneal part, detected by a Scheimpflug camera (Pentacam HR; Oculus $\mathrm{GmbH}$ ), compared to normal eyes [16]. Tan et al. evaluated optical quality changes in DED by using the Optical Quality Analysis System (OQAS II; Visiometrics S.L., Tarrasa, Spain). They analyzed aberrations and intraocular scattering by using the Objective Scatter Index (OSI) [17] and found that this parameter was increased in patients with DED, and its rate of change was correlated with severity of DED [18]. Furthermore, Ge et al. demonstrated that several parameters (OSI, OSI standard deviation, $\triangle \mathrm{OSI}, \triangle \mathrm{OSI} /$ time, blinking change, and blinking frequency) were correlated with BUT and staining score [19].

\section{Aberrometer}

Aberrometry uses wavefront sensing to analyze deviations in the wavefront exiting the eye from a reference wavefront. This technique is useful for measuring the complete refractive status, including irregular astigmatism, or any other optical irregularity [20].

Koh et al. demonstrated that BUT was associated with increased higher-order aberrations (HOAs) both in photopic and scotopic conditions [21]. Sequential measurement of HOAs demonstrated that normal eyes can be classified into three sub-groups as having stable, small-fluctuation, and sawtooth patterns, respectively. In the latter group, significant changes were found in the sequential post-blink changes in the coma-like and sphericallike aberrations and total HOAs [22]. In eyes with DED or irregularities in their refractive surfaces, dynamic wavefront analysis post-blink can detect an increase of the HOAs, and this is correlated with the OSDI score and BUT [23].

In patients with $\mathrm{DED}$, superficial punctate keratopathy may aggravate both baseline HOAs and sequential post-blink changes in HOAs [24]. In eyes with a short BUT, a prolonged blink interval leads to increased HOAs, suggesting that suppressed blinking (e.g., for workers who operate video display terminals), can result in reduced optical quality [25].

Deschamps et al. demonstrated the impact of tear film-related aberration changes on activities of daily living in DED, specifically during a driving simulator test [26].

An interventional study investigated the effects of topical drops (sodium hyaluronate) on dynamic aberrometry in patients with DED and discovered no significant changes [27]. On the other hand, another study examining the effect of rebamipide $2 \%$ (a mucin secretagogue) demonstrated decreased HOAs after 4 weeks of treatment in DED patients with short BUT [28]. 


\section{Anterior Segment Optical Coherence Tomography}

Optical coherence tomography (OCT) is a noninvasive technique developed to obtain tomographic image reconstruction of a biological tissue with a longitudinal and lateral spatial resolution of a few micrometers by using low-coherence interferometry [29,30]. Anterior segment OCT (AS-OCT) can obtain images of important structures of the ocular surface [31] and is a useful tool in the diagnosis and follow-up of several diseases of the anterior segment of the eye. In DED, the measurement of parameters of the tear film by means of AS-OCT, such as pre-corneal tear film thickness (TFT), tear meniscus height (TMH), curvature (TMR), cross-sectional area (TMA) and tear meniscus depth (TMD), are widely used in routine clinical practice thanks to the noncontact nature of these examination and the rapid image acquisition by the instrument $[32,33]$. The average value of TFT measured by AS-OCT in healthy subjects is approximately $5 \mu \mathrm{m}$, while it is reduced in DED patients. This reduction is correlated with objective and subjective assessments, such as BUT and OSDI [34]. The value of TFT increases up to $24 \mathrm{~h}$ with the topical administration of chitosan-N-acetylcysteine, perfluorohexyl octane or low-dose hydrocortisone [35,36], but is less influenced by low-viscosity agents. TMH and TMA are two useful biomarkers of DED, as suggested by the DEWS II Report. Spectral Domain AS-OCT demonstrated a sensitivity of $80.5 \%$ and $86.1 \%$ and a specificity of $89.3 \%$ and $85.3 \%$ for TMH and TMA, respectively; however, the diagnostic ability of evaporative DED was low $(<50 \%)$ [37]. In clinical practice, some confounding factors related to the environment or the ocular surface's anatomy (e.g., conjunctivochalasis, lid-parallel conjunctival folds, disorders of lid margin congruity) should be taken into account. AS-OCT is also useful for the 3D high-resolution of Meibomian glands (MG) [38]. In patients with Meibomian gland dysfunction (MGD), AS-OCT demonstrated a decreased MG length and width, which correlated with ocular discomfort symptoms and signs [39].

\section{In Vivo Confocal Microscopy}

In vivo confocal microscopy (IVCM) is a useful imaging technique for the in vivo microscopic observation of the corneal microstructure that enables clinicians to gain deep insight into the pathophysiology of ocular surface diseases [40]. Although it is a non/minimally invasive test, there are concerns about its routine use in clinical practice: (i) the examination requires direct contact with the ocular surface; (ii) a small field of view is obtained; (iii) only one z-plane is investigated; (iv) the eye tracker function is not feasible [41].

IVCM of the corneal epithelium demonstrated significant alterations in DED patients, presumably due to increased desquamation of the superficial cell layer caused by hyperosmolarity of the tear film associated with increased tear evaporation and elevated inflammatory mediators. Furthermore, IVCM allows the evaluation of immune and inflammatory cells, corneal nerves, keratocytes, and MG structures on a cellular level [42].

Several studies demonstrated a reduced density of superficial epithelial cells in Sjögren's and non-Sjögren's DED (respectively, PSDE and NSDE) [43]. Tuominen et al. reported a reduction in stromal thickness in patients with PSDE as well as abnormal keratocyte hyperreflectivity [44]. Benitez del Castillo et al. presented an increased density in anterior and posterior stromal cells in the PSDE group compared to the NSDE group, but without statistical significance [45].

In accordance with the recent evidence of neural dysregulation in DED, studies regarding corneal nerve parameters reported an increased tortuosity and reflectivity of the corneal sub-basal nerve plexus and an increased number of bead-like formations in both PSDE and NSDE compared to healthy controls [41,43]. The results obtained by Lin et al. demonstrated that there was also immune dysregulation: in fact, while in healthy subjects dendritic and leukocytes epithelial cells of the cornea decrease from the periphery towards to the center, in DED they show the opposite trend [46].

IVCM enables the visualization of the ultrastructure of MG [47-49]. Villani et al. demonstrated an increased acinar dilatation, a higher reflectivity (grades 1-4) of meibum, 
a decreased diameter of MG orifices and increased inhomogeneity of the acinar wall in patients with SS and MGD compared to controls [47]. Ibrahim et al. demonstrated a reduction in the density and diameters of the acinar units in MGD [49]. Randon et al., proposed a new classification of MGD based on IVCM findings (type 0 for normality, type 1 for meibum obstruction, type 2 for inflammation, and type 3 for fibrosis), and demonstrated a strong correlation between the IVCM score and the meibography scores [50]. In a crosssectional study, Zhao found that DED symptoms were negatively correlated with IVCM parameters of MG and positively correlated with conjunctival inflammatory cells [51].

\section{Meibography}

Meibography allows the observation of the morphological structure of the MG in a two-dimensional plane. The technique was introduced for the first time in 1977 by Tapie, who used transillumination from the palpebral skin with an illuminating probe to capture images of MGs. The approach was then refined by other methodologies that allow the visualization of MG on black-and-white film, on infrared film with a near-infrared CCD (charge-coupled device) camera, or with an infrared CCD camera [52]. Non-contact techniques based on an infrared filter and infrared CCD camera that made possible recording the transillumination image from the conjunctival side of the eyelid were developed in the last decade [53]. Non-contact meibography is based on the autofluorescence of a healthy meibum when illuminated with infrared light, which can be detected by an infrared chargecoupled device camera; thus, the glands appear as light areas against a darker background and any alterations in meibum or loss of acinar tissue appear as a dark area [54]. Recent technology has led to the development of several mobile, handheld, pen-shaped and multifunctionality (slit lamp-based, mobile and topography-equipped) systems with infrared light-emitting diodes fixed to infrared cameras that allow the capture of videos and images of MG and increase the feasibility of outpatient care assessment $[55,56]$.

In clinical practice, the grading systems of MG structures can be used to document the presence, progression, and treatment response to MGD [57]. The most useful systems are the Meiboscore and the Meibograde; both feature a score based on the percentage of loss of the glandular area, although the latter offers a higher sensitivity and should be able to detect minor changes in MG [58]. Gulmez Sevim et al. demonstrated that OSDI score, BUT and lissamine green staining were significantly correlated with MGD grade and MG area loss [59]. Although functional and morphological changes in MG are often thought to be well correlated [60], meibography alone does not appear to be sufficient for reaching the diagnosis of MGD, but it should be considered in the context of other clinical parameters (e.g., BUT, lid margin examination) or other imaging techniques (e.g., IVCM).

\section{Interferometry}

The tear film lipid layer is chiefly composed of meibomian lipid, which is derived from the marginal reservoirs of the lids. The lipid layer plays a critical role in tear film stability for the maintenance of ocular surface health by preventing excessive evaporation of the aqueous layer. In obstructive or hyposecretory MGD, thinning of the lipid layer leads to excessive evaporation, causing evaporative-type DED [61]. When adequate light hits an oily layer, the result is the generation of an interferometric fringe. Furthermore, interference patterns are produced due to the phase difference between the light reflected from the lipid layer and the light that is reflected from the corneal epithelium $[62,63]$. Interferences by thin films display different colors, depending on the thickness of the film, from a dark color, caused by a thinner film area, to a brighter color, caused by a thicker film area. Imaging-based ocular surface interferometry is a noninvasive technique that allows the measurement of lipid layer thickness (LLT) on a nanometer $(\mathrm{nm})$ scale.

In healthy eyes, LLT has been estimated and reported to be approximately $70 \mathrm{~nm}$. Various methods utilizing interference patterns have been used to characterize this parameter. In 1968, McDonald used a gooseneck light [64], in 1980 Hamano et al. a bio differential microscope [65], Polaroid filters [66], monochromatic light [67], spectral discrimination [68], 
and a simple interferometer made of paper tool for lipid layer evaluation [69]. There are several interference imaging devices: the DR-1 tear interference camera (Kowa Co., Nagoya, Japan) [70], the LipiView II interferometer (TearScience Inc., Morrisville, NC, USA) [71], the Lipiscanner 1.0 (Visual Optics, Chuncheon, Korea), an add-on to an existing slit lamp biomicroscope [72], the Oculus Keratograph 5M (Oculus, Arlington, WA, USA) [73], and the IDRA (Sbm Sistemi, Inc., Torino, Italy) [74,75].

The DR- $1 \alpha$ camera allows a qualitative analysis of the lipid layer. Yokoi et al. proposed a grading system based on the first stable frames from the DR- $1 \alpha$ camera [76].

Goto et al. produced a computer-synthesized color chart of a human tear lipid interference image for the conversion from tear interference color information to tear lipid layer film thickness data [77]. By using the DR- $1 \alpha$ camera, it is possible to evaluate the kinetic spread and stability of the lipid layer. Goto et al. evaluated the speed and pattern of lipid spread after eye opening and the stability of the lipid film after spread, and found that in patients with lipid layer deficiency, the lipid spread was slow and resulted in a vertically streaking and non-uniform pattern [78]. Arita et al. demonstrated that the DR- $1 \alpha$ interferometer can measure the TMH as reliably as AS-OCT and that the interferometric TMH correlated with Schirmer's score. [79]. DR-1 $\alpha$ interferometry device can assist in the differential diagnosis of different subtypes of DED; indeed, Arita et al., by comparing three interferometric patterns (pearl-like, Jupiter-like, or crystal-like), found a direct correlation with BUT, NIBUT and Schirmer test value [80].

The LipiView II (LVII) interferometer can quantitatively measure the average LLT by analyzing the interferometric pattern of the tear film, a partial blink rate, and uses an infrared light source for imaging the MG. Lee Y. et al. showed that the average LLT value has a significantly positive correlation with age, OSDI, and Ocular Staining Score, and no correlation with the Schirmer test type I, BUT, or meiboscore [81]. By using LVII, Weng demonstrated that younger patients with DED experienced more severe subjective symptoms, more incomplete blinks, and a thinner LLT [82].

\section{Thermography}

The stability of the tear film is strictly linked to the integrity of the lipid layer that controls evaporation. There is currently no commercially available instrument dedicated to the detection of tear film evaporation, but thermography permits an indirect evaluation of the evaporation rate by measuring the temperature of the ocular surface in a noninvasive manner, using a thermographic camera operating within the infrared range [83-85]. In 1995, Morgan et al., measured ocular surface temperature in patients with DED and reported that the surface temperature was significantly higher than in normal eyes, while the temperature at the center of the cornea of DED eyes became lower than that in normal eyes after sustained eye opening [86]. In the last decade, advances in technology have allowed the measurement of the ocular surface temperature with increasing accuracy, resolution, and speed [87]. Su et al., showed a strong spatial and temporal correlation between BUT and tear film evaporation [88].

Kamao et al. reported that DED was associated with a greater decrease in the ocular surface temperature at $10 \mathrm{~s}$ after eye opening and suggested that measurements obtained over 10 s have sensitivity and specificity values of 0.83 and 0.80 , respectively, for screening DED eyes [87].

\section{Bulbar Redness Assessment}

Bulbar redness (BR) is a non-specific ocular condition caused by the vasodilation of the conjunctival and/or anterior scleral blood vessels, which is itself caused by enhanced blood flow to and capillary permeability in the anterior ocular tissues in response to various stimuli [89]. Hyperemia is a feature of several ocular conditions: inflammation of the anterior segment of the eye [90], the adverse effects of glaucoma medications [91,92], contact lens wearing [93], allergic or infective conjunctivitis [94], and DED [95]. 
Since the first introduction by McMonnies and Chapman-Davies in 1987 of an imagebased bulbar hyperemia grading scale [89], several subjective rating scales have been introduced to improve inter- or intra-observer variability $[96,97]$. Scientific studies tried to overcome these limitations by developing novel models of computer-based photographanalysis techniques, which have now progressed to automated image analysis through the application of artificial intelligence (AI) [98]. Villumesen et al. developed the first computerassisted conjunctival hyperemia quantification system by using the pixel edge detection analysis of a $3 \times 3 \mathrm{~mm}$ region of bulbar conjunctiva [99]. Willingham analyzed the mean relative redness (RR) and the blood vessel area ratio (VA) of digital images of the external eye by using a clinical photographic biomicroscope, an MVC video camera and computer imaging system, and custom software [100]. Rodriguez et al. developed an automated computer redness grading system (Ora, Inc., Andover, MA, USA, patent pending) for the evaluation of the location and prominence of fine horizontal conjunctival vessels in DED and demonstrated agreement with a group of investigators using the established clinical scale [101].

Wu et al. evaluated the clinical assessment of bulbar redness by using an Oculus Keratograph 5M Topographer (Oculus Optikgerate $\mathrm{GmbH}$, Wetzlar, Germany) equipped with automated scanning and scoring software. They found a statistically significant correlation between the Oculus Index score and the scores determined using three subjective scales (the Institute for Eye Research scale, the Efron scale, and the Validated Bulbar Redness 10-picture grading scale) [96,102]. Moreover, they found that the Keratograph yielded higher intra- and inter-observer reproducibility, suggesting that the Keratograph could be a time-saving device [103].

Despite the introduction of novel incorporated instruments that make the clinical assessment of BR in DED quicker and easier, the majority of automatic grading systems are unable to differentiate bulbar conjunctival hyperemia from episcleral and scleral hyperemia; thus, there are many concerns over the use of BR as a biomarker [104].

\section{Image Modality Based Computerized Detection Techniques}

Through recent advances in $\mathrm{AI}$ and the rapid progression of analytic techniques, researchers are trying to overcome the main pitfalls of clinical testing, such as the long time required for acquisition and the need for skillful maneuvers [105]. The aim of the computerization of clinical tests is to help clinicians to increase accuracy and reduce the time taken to form a diagnosis.

In the last decade, several computerized DED detection techniques have been proposed, each based on different technologies. The first attempt to automatically detect DED was undertaken by Yedidya et al., who used a multi-step algorithm to evaluate BUT from an eye video that was captured using an Eyescan device [106]. Ramos et al. proposed an automatic methodology for characterizing tear film dynamics over the exposed corneal surface from the emergence of the first break-up in the tear film until the subsequent blink. To this end, the BUT measurement was computed, and the break-up areas were segmented in each video frame to analyze other break-up parameters, such as the size or spatial extension of the BUT [107]. Su et al. proposed an automatic method to detect the BUT area using a deep learning convolutional neural network $(\mathrm{CNN})$ model, a hierarchical multilayered neural network that can learn visual patterns directly from image pixels [108,109]. The proposed CNN model detected break-up with an accuracy rate of $98 \%$ [110].

Two techniques based on the interference pattern of the lipid layer have been proposed. The first is a computer-aided system to support DED diagnosis based on tear film maps (CASDES), and the second is called iDEAS. The former system, which analyzes the images acquired by Tearscope, allows the recognition of dry area regions in agreement with the region annotated manually by the ophthalmologist [111]. The latter is a web-based system for DED assessment, in which, once the patient's interference pattern images are uploaded, a support vector machine classifier based on statistical learning theory allocates the images into five categories based on Guillon classification [112,113]. 
Acharya et al. developed a technique based on thermal infrared images. The result produced by this technique is binary; that is, input images of either normal eye or dry eye are converted into 1D data and then fed into different classifiers, such as k-Nearest Neighbor (KNN), decision tree, Probabilistic Neural Network (PNN), SVM and Naive Bayes (NB). The authors obtained an average sensitivity of $99.8 \%$, specificity of $99.8 \%$ and classification accuracy of $99.8 \%$ using PNN and KNN classifier [114].

\section{Pros and Cons of Noninvasive DED Imaging}

The novel non-invasive diagnostic techniques for DED offer numerous advantages over conventional tests. The main advantage is related to their automated nature, which means that they do not require the clinician's judgment to determine a score. This is clinically relevant as subjective DED markers, such as fluorescein BUT and corneal staining, feature low inter-observer repeatability due to their lack of standardization [4]. Moreover, most of these novel diagnostic techniques do not require direct contact with the eye, and therefore have little/no effect on the volume and properties of the tear film. Thus, they can be used as screening tools (e.g., prior to ocular surgery) by trained medical personnel (not necessarily an ophthalmologist), before proceeding with more invasive ocular surface examinations in case of the detection of abnormal values. Furthermore, they provide clear and detailed reports summarizing all the results of the tests for each patient examination, which can be used for future reference and comparison (Figures 1 and 2).

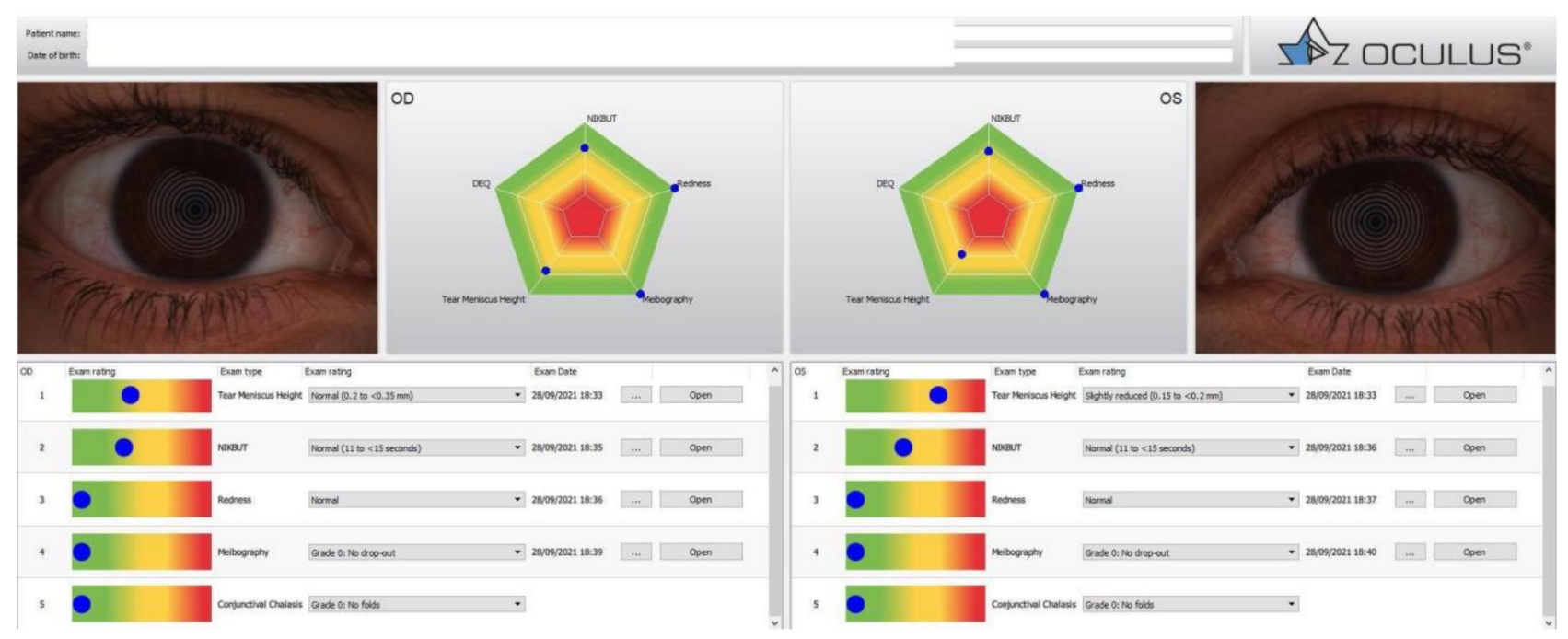

Figure 1. Dry eye report obtained with the use of Keratograph $5 \mathrm{M}$ (Oculus Optikgeräte GmbH, Wetzlar, Germany). A combination of five parameters, including tear meniscus height, non-invasive break-up time, redness, meibography, and conjunctival chalasis, is displayed on a radar chart in a pentagonal shape.

The daily report is useful for educating patients and encouraging treatment compliance: "A picture is truly worth a thousand words". All-in-one devices (one machine for more tasks) make it possible to reach the diagnosis of DED in less time compared to a traditional workup (e.g., 3 min are enough to perform a complete ocular surface workup with Idra), and represent a guide for imaging-based treatment: the deficient layer(s) of the tear film is/are identified and a targeted therapy can be prescribed. Similarly, monitoring patient's course over time is also made easier by using these devices and the trend of a single parameter (e.g., NIBUT) after a given therapy can be graphically reported and analyzed (Figure 3). 


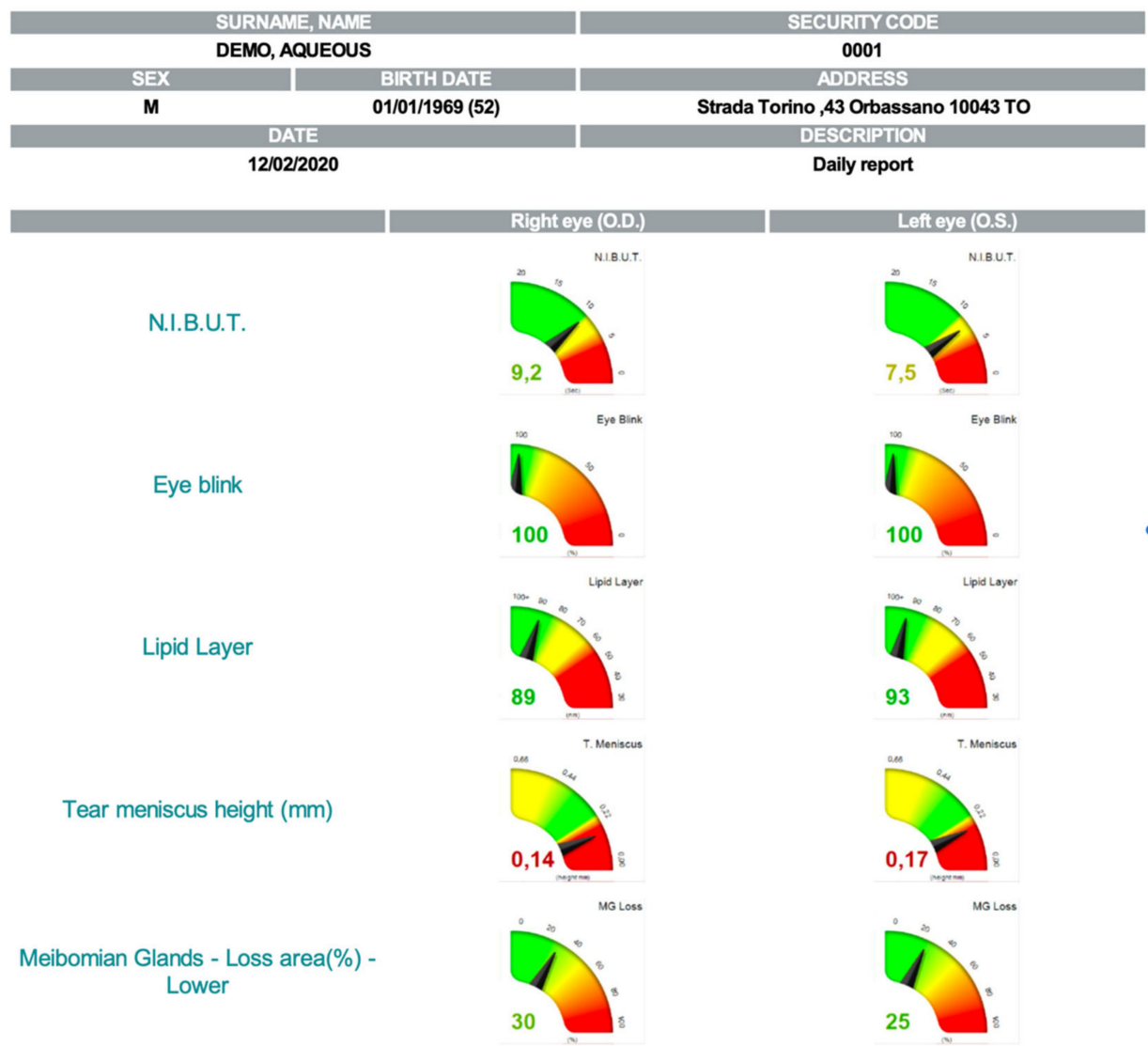

Figure 2. Dry Eye report obtained with the use of IDRA (Sbm Sistemi, Inc., Torino, Italy), including noninvasive break-up time, eye blink, lipid layer, tear meniscus height, and loss area of meibomian glands.

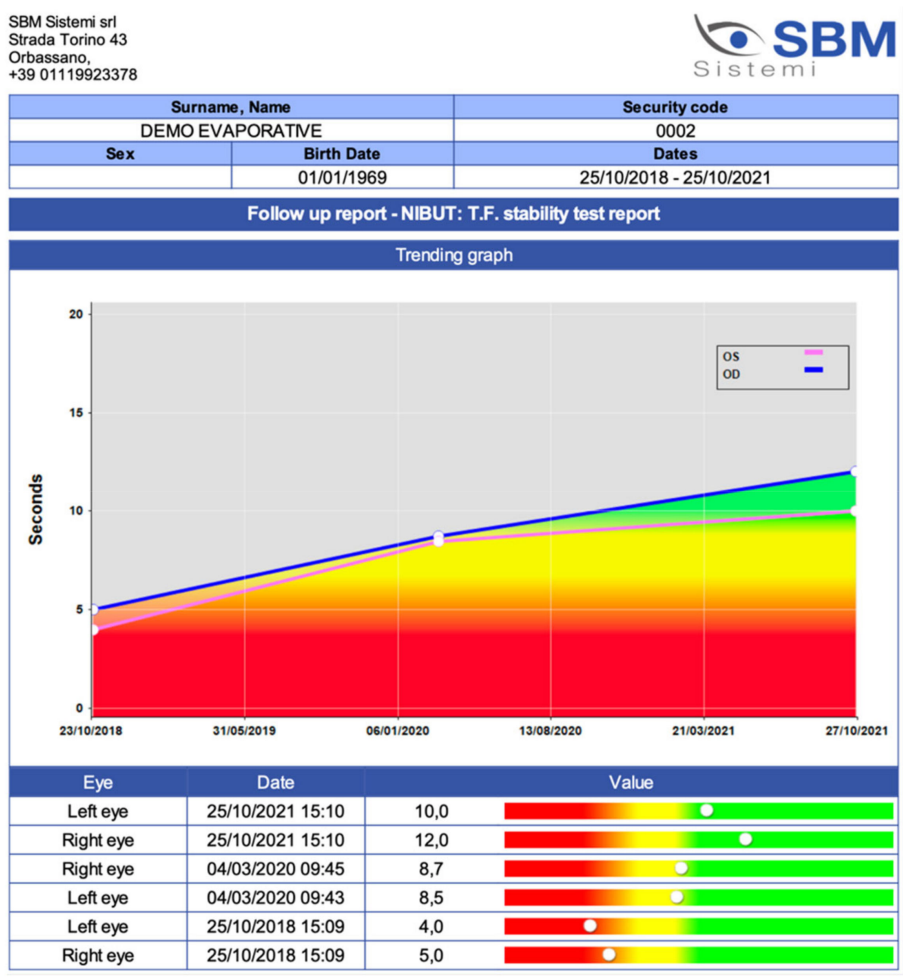

Figure 3. Trending graph obtained with the use of IDRA (Sbm Sistemi, Inc., Torino, Italy) related to noninvasive break-up time values collected at different time points. 
Nevertheless, there are some drawbacks to these new diagnostic techniques that need to be mentioned. In particular, the cost may represent a major limitation for their widespread acceptance, and cost-effectiveness evaluations are still required to support their adoption on a large scale. Moreover, ophthalmological conditions other than DED may cause some phenomena that reduce the diagnostic accuracy, particularly if the image interpretations are not performed by an ophthalmologist and/or if the slit lamp examination is not performed. For instance, conjunctivochalasis may hamper the accurate measurement of $\mathrm{TMH}$, leading to overestimation of the value (Figure 4), while conjunctival lesions, such as pterygium, may significantly alter bulbar redness by increasing its value in the affected area (Figure 5). It should also be noted that novel tests cannot yet replace all the traditional DED metrics and slit lamp examination is still required to complete the diagnostic workup.

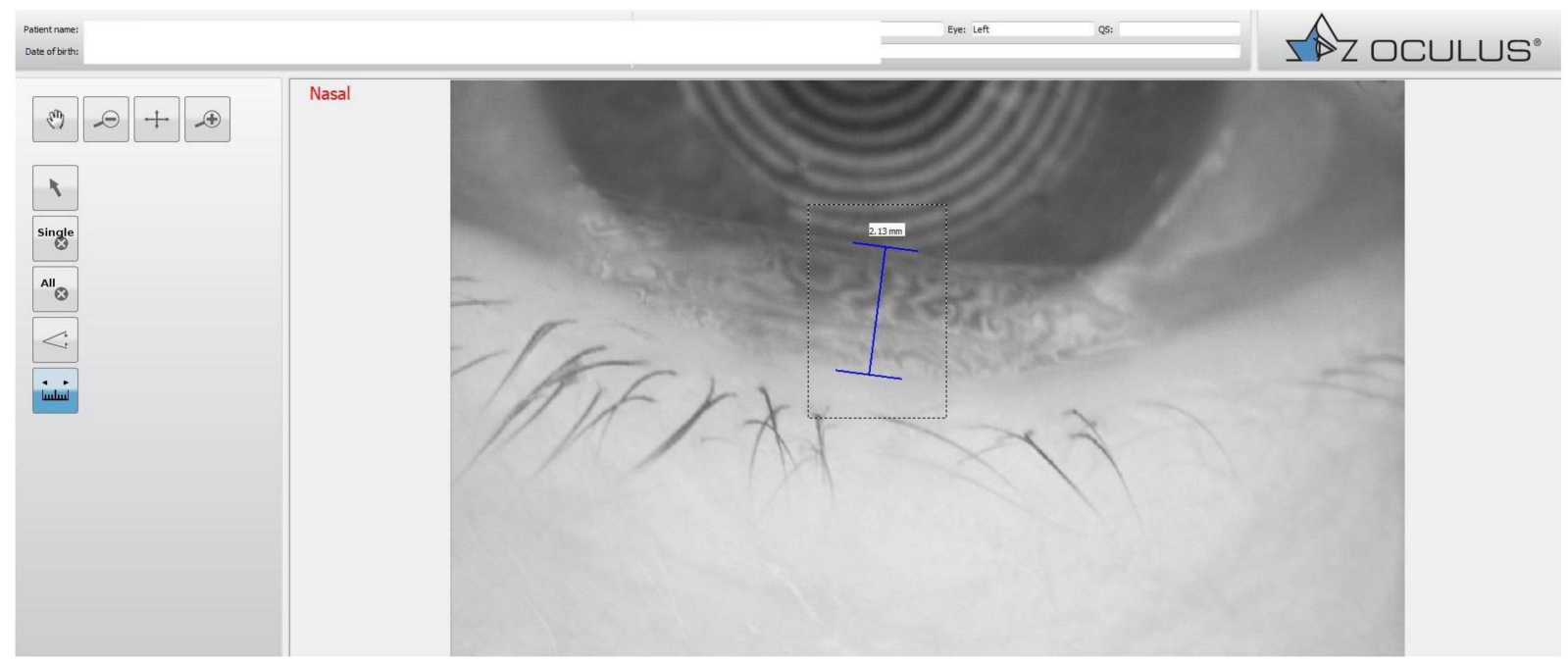

Figure 4. Tear meniscus height measurement artifact due to the presence of conjunctivochalasis. Image obtained with Keratograph5 M (Oculus Optikgeräte GmbH, Wetzlar, Germany).

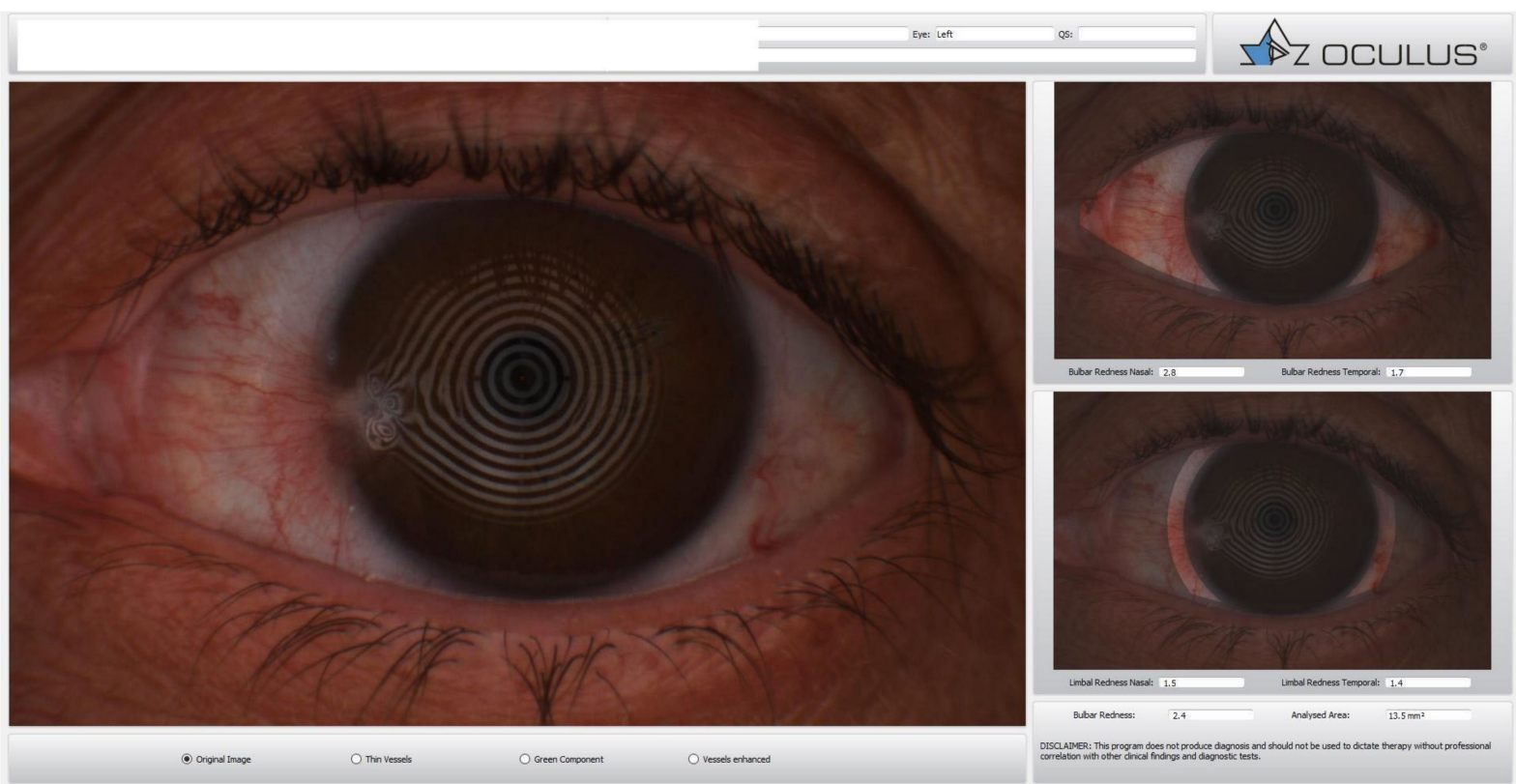

Figure 5. Redness artefact due to the presence of a wing-shaped pterygium. Image obtained with Keratograph5 M (Oculus Optikgeräte GmbH, Wetzlar, Germany). 
Finally, we would like to provide some recommendations for the improved use of noninvasive diagnostic tools. Firstly, as in traditional DED tests, in the noninvasive workup attention should be paid to the order in which diagnostic exams are performed. In fact, although these tests usually do not require contact with the ocular surface, lightinduced tearing should be considered, since it could influence the results of subsequent examinations. Secondly, in the case of significant differences between the two eyes of the same patient, results should be interpreted with caution, and multiple evaluations of both eyes are advisable.

\section{Conclusions}

DED represents a very frequent ocular disease worldwide and its prevalence is continuously growing [115]. Several diagnostic tools have recently been introduced in clinical practice to assist clinicians in the (early) diagnosis and monitoring of DED; furthermore, these devices allow the identification of the affected layer(s) of the tear film and represent a guide for imaging-based targeted treatment. The information generated provides objective results and pictures that are useful for helping patients' awareness about DED, thus improving treatment compliance. Soon, the advent of AI may further help clinicians in this complex diagnostic pathway. In this direction, further, larger-scale, clinical trials should provide more evidence on the role of these emerging diagnostic techniques in the DED diagnostic battery by establishing universal cut-off values for each exam.

Author Contributions: Conceptualization, L.D.C. and G.G.; methodology, L.D.C.; formal analysis, G.G.; data curation, L.D.C., M.P., A.V., M.B., L.F.D., V.S., C.E.T., G.G.; writing-original draft preparation, L.D.C., M.P., M.B.; writing-review and editing, L.D.C., M.P., A.V., G.G.; supervision, V.S., C.E.T.; project administration, V.S., C.E.T. All authors have read and agreed to the published version of the manuscript.

Funding: This research received no external funding.

Institutional Review Board Statement: Not applicable.

Informed Consent Statement: Not applicable.

Conflicts of Interest: The authors declare no conflict of interest.

\section{References}

1. Lemp, M.A.; Foulks, G.N. The Epidemiology of Dry Eye Disease: Report of the Epidemiology Subcommittee of the International Dry Eye WorkShop (2007). Ocul. Surf. 2007, 5, 93-107. [CrossRef]

2. Stapleton, F.; Alves, M.; Bunya, V.Y.; Jalbert, I.; Lekhanont, K.; Malet, F.; Na, K.-S.; Schaumberg, D.; Uchino, M.; Vehof, F.; et al. TFOS DEWS II Epidemiology Report. Ocul. Surf. 2017, 15, 334-365. [CrossRef]

3. McDonald, M.; Patel, D.A.; Keith, M.S.; Snedecor, S.J. Economic and Humanistic Burden of Dry Eye Disease in Europe, North America, and Asia: A Systematic Literature Review. Ocul. Surf. 2016, 14, 144-167. [CrossRef] [PubMed]

4. Wolffsohn, J.S.; Arita, R.; Chalmers, R.; Djalilian, A.; Dogru, M.; Dumbleton, K.; Gupta, P.K.; Karpecki, P.; Lazreg, S.; Pult, H.; et al. TFOS DEWS II Diagnostic Methodology report. Ocul. Surf. 2017, 15, 539-574. [CrossRef] [PubMed]

5. Schmidl, D.; Schlatter, A.; Chua, J.; Tan, B.; Garhöfer, G.; Schmetterer, L. Novel Approaches for Imaging-Based Diagnosis of Ocular Surface Disease. Diagnostics 2020, 10, 589. [CrossRef]

6. Vigo, L.; Pellegrini, M.; Bernabei, F.; Carones, F.; Scorcia, V.; Giannaccare, G. Diagnostic Performance of a Novel Noninvasive Workup in the Setting of Dry Eye Disease. J. Ophthalmol. 2020, 2020, 5804123 . [CrossRef]

7. Aragona, P.; Giannaccare, G.; Mencucci, R.; Rubino, P.; Cantera, E.; Rolando, M. Modern approach to the treatment of dry eye, a complex multifactorial disease: A P.I.C.A.S.S.O. board review. Br. J. Ophthalmol. 2021, 105, 446-453. [CrossRef]

8. Willcox, M.D.P.; Argüeso, P.; Georgiev, G.A.; Holopainen, J.M.; Laurie, G.W.; Millar, T.J.; Papas, E.B.; Rolland, J.P.; Schmidt, T.A.; Stahl, U.; et al. TFOS DEWS II Tear Film Report. Ocul. Surf. 2017, 15, 366-403. [CrossRef]

9. Herbaut, A.; Liang, H.; Denoyer, A.; Baudouin, C.; Labbé, A. Tear film analysis and evaluation of optical quality: A review of the literature. J. Fr. Ophtalmol. 2019, 42, 226-243. [CrossRef]

10. Giannaccare, G.; Scorcia, V. False Myths versus Medical Facts: Ten Common Misconceptions Related to Dry Eye Disease. Biomedicines 2020, 8, 172. [CrossRef]

11. Bandlitz, S.; Peter, B.; Pflugi, T.; Jaeger, K.; Anwar, A.; Bikhu, P.; Nosch, D.S.; Wolffsohn, J.S. Agreement and repeatability of four different devices to measure non-invasive tear breakup time (NIBUT). Contact Lens Anterior Eye 2020, 43, 507-511. [CrossRef] 
12. Yeo, S.; Lee, R.; Aung, H.T.; Tong, L. Agreement of non-invasive tear break up time measurement between Tomey RT-7000 Auto Refractor-Keratometer and Oculus Keratograph 5M. Clin. Ophthalmol. 2016, 10, 1785-1790. [CrossRef] [PubMed]

13. Fuller, D.G.; Potts, K.; Kim, J. Noninvasive Tear Breakup Times and Ocular Surface Disease. Optom. Vis. Sci. 2013, 90, 1086-1091. [CrossRef]

14. Hong, J.; Sun, X.; Wei, A.; Cui, X.; Li, Y.; Qian, T.; Wang, W.; Xu, J. Assessment of Tear Film Stability in Dry Eye With a Newly Developed Keratograph. Cornea 2013, 32, 716-721. [CrossRef] [PubMed]

15. Goto, E.; Yagi, Y.; Matsumoto, Y.; Tsubota, K. Impaired functional visual acuity of dry eye patients. Am. J. Ophthalmol. 2002, 133, 181-186. [CrossRef]

16. Koh, S.; Maeda, N.; Ikeda, C.; Asonuma, S.; Mitamura, H.; Oie, Y.; Soma, T.; Tsujikawa, M.; Kawasaki, S.; Nishida, K. Ocular Forward Light Scattering and Corneal Backward Light Scattering in Patients with Dry Eye. Investig. Opthalmol. Vis. Sci. 2014, 55, 6601-6606. [CrossRef] [PubMed]

17. Galliot, F.; Patel, S.R.; Cochener, B. Objective Scatter Index: Working Toward a New Quantification of Cataract? J. Refract. Surg. 2016, 32, 96-102. [CrossRef]

18. Tan, C.; Labbé, A.; Liang, Q.; Qiao, L.; Baudouin, C.; Wan, X.; Wang, N. Dynamic Change of Optical Quality in Patients With Dry Eye Disease. Investig. Opthalmol. Vis. Sci. 2015, 56, 2848-2854. [CrossRef]

19. Ye, F.; Jiang, F.; Lu, Y.; Xue, C.Y.; Zhu, X.M.; Wu, Y.; Huang, Z.P. Objective optical assessment of tear-film quality dynamics in patients with meibomian gland dysfunction and aqueous-deficient dry eye optical quality changes in different dry eye subtypes. Indian J. Ophthalmol. 2019, 67, 599-603. [CrossRef]

20. Maeda, N. Clinical applications of wavefront aberrometry - a review. Clin. Exp. Ophthalmol. 2009, 37, 118-129. [CrossRef]

21. Koh, S.; Maeda, N.; Kuroda, T.; Hori, Y.; Watanabe, H.; Fujikado, T.; Tano, Y.; Hirohara, Y.; Mihashi, T. Effect of tear film break-up on higher-order aberrations measured with wavefront sensor. Am. J. Ophthalmol. 2002, 134, 115-117. [CrossRef]

22. Koh, S. Serial Measurements of Higher-Order Aberrations after Blinking in Normal Subjects. Investig. Opthalmol. Vis. Sci. 2006, 47, 3318-3324. [CrossRef]

23. Denoyer, A.; Rabut, G.; Baudouin, C. Tear Film Aberration Dynamics and Vision-Related Quality of Life in Patients with Dry Eye Disease. Ophthalmology 2012, 119, 1811-1818. [CrossRef] [PubMed]

24. Koh, S.; Maeda, N.; Hirohara, Y.; Mihashi, T.; Bessho, K.; Hori, Y.; Inoue, T.; Watanabe, H.; Fujikado, T.; Tano, Y. Serial Measurements of Higher-Order Aberrations after Blinking in Patients with Dry Eye. Investig. Opthalmol. Vis. Sci. 2008, 49, 133-138. [CrossRef]

25. Koh, S.; Maeda, N.; Hori, Y.; Inoue, T.; Watanabe, H.; Hirohara, Y.; Mihashi, T.; Fujikado, T.; Tano, Y. Effects of Suppression of Blinking on Quality of Vision in Borderline Cases of Evaporative Dry Eye. Cornea 2008, 27, 275-278. [CrossRef] [PubMed]

26. Deschamps, N.; Ricaud, X.; Rabut, G.; Labbé, A.; Baudouin, C.; Denoyer, A. The Impact of Dry Eye Disease on Visual Performance While Driving. Am. J. Ophthalmol. 2013, 156, 184-189.e3. [CrossRef] [PubMed]

27. Lekhanont, K.; Chuckpaiwong, V.; Vongthongsri, A.; Sangiampornpanit, T. Effects of Sodium Hyaluronate on Wavefront Aberrations in Dry Eye Patients. Optom. Vis. Sci. 2014, 91, 39-46. [CrossRef]

28. Koh, S.; Inoue, Y.; Sugmimoto, T.; Maeda, N.; Nishida, K. Effect of Rebamipide Ophthalmic Suspension on Optical Quality in the Short Break-up Time Type of Dry Eye. Cornea 2013, 32, 1219-1223. [CrossRef] [PubMed]

29. Huang, D.; Swanson, E.A.; Lin, C.P.; Schuman, J.S.; Stinson, W.G.; Chang, W.; Hee, M.R.; Flotte, T.; Gregory, K.; Puliafito, C.A.; et al. Optical Coherence Tomography. Science 1991, 254, 1178-1181. [CrossRef]

30. Pellegrini, M.; Vagge, A.; Desideri, L.F.F.; Bernabei, F.; Triolo, G.; Mastropasqua, R.; Del Del Noce, C.; Borrelli, E.; Sacconi, R.; Iovino, C.; et al. Optical Coherence Tomography Angiography in Neurodegenerative Disorders. J. Clin. Med. 2020, 9, 1706. [CrossRef]

31. Ang, M.; Baskaran, M.; Werkmeister, R.M.; Chua, J.; Schmidl, D.; dos Santos, V.A.; Garhöfer, G.; Mehta, J.S.; Schmetterer, L. Anterior segment optical coherence tomography. Prog. Retin. Eye Res. 2018, 66, 132-156. [CrossRef]

32. Cui, L.; Wang, J.; Perez, V.L.; Shen, M.; Yuan, Y.; Wang, M.R. Visualization of the Precorneal Tear Film Using Ultrahigh Resolution Optical Coherence Tomography in Dry Eye. Eye Contact Lens Sci. Clin. Pract. 2012, 38, 240-244. [CrossRef]

33. Ramos, J.L.B.; Li, Y.; Huang, D. Clinical and research applications of anterior segment optical coherence tomography-a review. Clin. Exp. Ophthalmol. 2009, 37, 81-89. [CrossRef]

34. Schmidl, D.; Witkowska, K.J.; Kaya, S.; Baar, C.; Faatz, H.; Nepp, J.; Unterhuber, A.; Werkmeister, R.M.; Garhofer, G.; Schmetterer, L. The Association between Subjective and Objective Parameters for the Assessment of Dry-Eye Syndrome. Investig. Ophthalmol. Vis. Sci. 2015, 56, 1467-1472. [CrossRef]

35. Kallab, M.; Szegedi, S.; Hommer, N.; Stegmann, H.; Kaya, S.; Werkmeister, R.M.; Schmidl, D.; Schmetterer, L.; Garhöfer, G. Topical Low Dose Preservative-Free Hydrocortisone Reduces Signs and Symptoms in Patients with Chronic Dry Eye: A Randomized Clinical Trial. Adv. Ther. 2020, 37, 329-341. [CrossRef] [PubMed]

36. Schmidl, D.; Bata, A.M.; Szegedi, S.; Dos Santos, V.A.; Stegmann, H.; Fondi, K.; Krösser, S.; Werkmeister, R.M.; Schmetterer, L.; Garhöfer, G. Influence of Perfluorohexyloctane Eye Drops on Tear Film Thickness in Patients with Mild to Moderate Dry Eye Disease: A Randomized Controlled Clinical Trial. J. Ocul. Pharmacol. Ther. 2020, 36, 154-161. [CrossRef]

37. Binotti, W.W.; Bayraktutar, B.; Ozmen, M.C.; Cox, S.M.; Hamrah, P. A Review of Imaging Biomarkers of the Ocular Surface. Eye Contact Lens Sci. Clin. Pract. 2020, 46, S84-S105. [CrossRef] [PubMed] 
38. Hwang, H.S.; Shin, J.G.; Lee, B.H.; Eom, T.J.; Joo, C.-K. In Vivo 3D Meibography of the Human Eyelid Using Real Time Imaging Fourier-Domain OCT. PLoS ONE 2013, 8, e67143. [CrossRef] [PubMed]

39. Liang, Q.; Pan, Z.; Zhou, M.; Zhang, Y.; Wang, N.; Li, B.; Baudouin, C.; Labbé, A. Evaluation of Optical Coherence Tomography Meibography in Patients With Obstructive Meibomian Gland Dysfunction. Cornea 2015, 34, 1193-1199. [CrossRef]

40. Wang, Y.E.; Tepelus, T.C.; Vickers, L.A.; Baghdasaryan, E.; Gui, W.; Huang, P.; Irvine, J.A.; Sadda, S.; Hsu, H.Y.; Lee, O.L. Role of in vivo confocal microscopy in the diagnosis of infectious keratitis. Int. Ophthalmol. 2019, 39, 2865-2874. [CrossRef]

41. Niederer, R.; McGhee, C. Clinical in vivo confocal microscopy of the human cornea in health and disease. Prog. Retin. Eye Res. 2010, 29, 30-58. [CrossRef]

42. Giannaccare, G.; Pellegrini, M.; Sebastiani, S.; Moscardelli, F.; Versura, P.; Campos, E.C. In vivo confocal microscopy morphometric analysis of corneal subbasal nerve plexus in dry eye disease using newly developed fully automated system. Graefe's Arch. Clin. Exp. Ophthalmol. 2019, 257, 583-589. [CrossRef]

43. Villani, E.; Galimberti, D.; Viola, F.; Mapelli, C.; Ratiglia, R. The Cornea in Sjögren's Syndrome: An In Vivo Confocal Study. Investig. Opthalmol. Vis. Sci. 2007, 48, 2017-2022. [CrossRef] [PubMed]

44. Tuominen, I.S.J.; Konttinen, Y.T.; Vesaluoma, M.H.; Moilanen, J.A.O.; Helinto, M.; Tervo, T.M.T. Corneal Innervation and Morphology in Primary Sjögren's Syndrome. Investig. Opthalmol. Vis. Sci. 2003, 44, 2545-2549. [CrossRef]

45. Del Castillo, J.M.B.; Wasfy, M.A.S.; Fernandez, C.; Garcia-Sanchez, J. An In Vivo Confocal Masked Study on Corneal Epithelium and Subbasal Nerves in Patients with Dry Eye. Investig. Opthalmol. Vis. Sci. 2004, 45, 3030-3035. [CrossRef]

46. Lin, H.; Li, W.; Dong, N.; Chen, W.; Liu, J.; Chen, L.; Yuan, H.; Geng, Z.; Liu, Z. Changes in Corneal Epithelial Layer Inflammatory Cells in Aqueous Tear-Deficient Dry Eye. Investig. Opthalmol. Vis. Sci. 2010, 51, 122-128. [CrossRef]

47. Villani, E.; Ceresara, G.; Beretta, S.; Magnani, F.; Viola, F.; Ratiglia, R. In Vivo Confocal Microscopy of Meibomian Glands in Contact Lens Wearers. Investig. Opthalmol. Vis. Sci. 2011, 52, 5215-5219. [CrossRef]

48. Matsumoto, Y.; Sato, E.A.; Ibrahim, O.M.; Dogru, M.; Tsubota, K. The application of in vivo laser confocal microscopy to the diagnosis and evaluation of meibomian gland dysfunction. Mol. Vis. 2008, 14, 1263-1271.

49. Ibrahim, O.M.; Matsumoto, Y.; Dogru, M.; Adan, E.S.; Wakamatsu, T.H.; Goto, T.; Negishi, K.; Tsubota, K. The Efficacy, Sensitivity, and Specificity of In Vivo Laser Confocal Microscopy in the Diagnosis of Meibomian Gland Dysfunction. Ophthalmology 2010, 117, 665-672. [CrossRef] [PubMed]

50. Randon, M.; Aragno, V.; Abbas, R.; Liang, H.; Labbé, A.; Baudouin, C.; Hong, L. In vivo confocal microscopy classification in the diagnosis of meibomian gland dysfunction. Eye 2018, 33, 754-760. [CrossRef] [PubMed]

51. Zhao, H.; Chen, J.-Y.; Wang, Y.-Q.; Lin, Z.-R.; Wang, S. In vivo Confocal Microscopy Evaluation of Meibomian Gland Dysfunction in Dry Eye Patients with Different Symptoms. Chin. Med. J. (Engl.) 2016, 129, 2617-2622. [CrossRef]

52. Arita, R. Meibography: A Japanese Perspective. Investig. Opthalmol. Vis. Sci. 2018, 59, DES48-DES55. [CrossRef]

53. Robin, J.B.; Jester, J.V.; Nobe, J.; Nicolaides, N.; Smith, R.E. In Vivo Transillumination Biomicroscopy and Photography of Meibomian Gland Dysfunction. Ophthalmology 1985, 92, 1423-1426. [CrossRef]

54. Giannaccare, G.; Bonifazi, F.; Sebastiani, S.; Sessa, M.; Pellegrini, M.; Arpinati, M.; Moscardelli, F.; Versura, P.; Campos, E. Meibomian Gland Dropout in Hematological Patients Before Hematopoietic Stem Cell Transplantation. Cornea 2018, 37, 12641269. [CrossRef]

55. Arita, R.; Itoh, K.; Maeda, S.; Maeda, K.; Amano, S. A Newly Developed Noninvasive and Mobile Pen-Shaped Meibography System. Cornea 2013, 32, 242-247. [CrossRef]

56. Pult, H.; Riede-Pult, B. Non-contact meibography: Keep it simple but effective. Contact Lens Anterior Eye 2012, 35, 77-80. [CrossRef] [PubMed]

57. Bernabei, F.; Versura, P.; Pellegrini, M.; Moscardelli, F.; Bonifazi, F.; Sessa, M.; Arpinati, M.; Scorcia, V.; Giannaccare, G. Longitudinal Analysis of Infrared Meibography in Patients Undergoing Hematopoietic Stem Cell Transplantation. Cornea 2020, 39, 812-817. [CrossRef] [PubMed]

58. Wise, R.J.; Sobel, R.K.; Allen, R.C. Meibography: A review of techniques and technologies. Saudi J. Ophthalmol. 2012, 26, 349-356. [CrossRef]

59. Sevim, D.G.; Gumus, K.; Unlu, M. Reliable, Noncontact Imaging Tool for the Evaluation of Meibomian Gland Function: Sirius Meibography. Eye Contact Lens Sci. Clin. Pract. 2020, 46, S135-S140. [CrossRef]

60. Kim, H.M.; Eom, Y.; Song, J.S. The Relationship between Morphology and Function of the Meibomian Glands. Eye Contact Lens Sci. Clin. Pract. 2018, 44, 1-5. [CrossRef]

61. Abusharha, A.A.; Pearce, E.I. The Effect of Low Humidity on the Human Tear Film. Cornea 2013, 32, 429-434. [CrossRef] [PubMed]

62. Doane, M.G. An Instrument for In Vivo Tear Film Interferometry. Optom. Vis. Sci. 1989, 66, 383-388. [CrossRef]

63. Yokoi, N.; Yamada, H.; Mizukusa, Y.; Bron, A.J.; Tiffany, J.M.; Kato, T.; Kinoshita, S. Rheology of Tear Film Lipid Layer Spread in Normal and Aqueous Tear-Deficient Dry Eyes. Investig. Opthalmol. Vis. Sci. 2008, 49, 5319-5324. [CrossRef] [PubMed]

64. McDonald, J.E. Surface phenomena of tear films. Trans. Am. Ophthalmol. Soc. 1968, 66, 905-939. [CrossRef]

65. Hamano, H.; Hori, M.; Kawabe, H.; Umeno, M.; Mitsunaga, S.; Ohnishi, Y.; Koma, I. Clinical Applications Of Bio Differential Interference Microscope. Contact Intraocular Lens Med. J. 1980, 6, 229-235.

66. Guillon, J.-P. Tear film photography and contact lens wear. J. Br. Contact Lens Assoc. 1982, 5, 84-87. [CrossRef] 
67. Doane, M.G.; Lee, M.E. Tear Film Interferometry as a Diagnostic Tool for Evaluating Normal and Dry-Eye Tear Film. Adv. Exp. Med. Biol. 1998, 438, 297-303.

68. Khamene, A.; Negahdaripour, S.; Tseng, S. A spectral-discrimination method for tear-film lipid-layer thickness estimation from fringe pattern images. IEEE Trans. Biomed. Eng. 2000, 47, 249-258. [CrossRef]

69. Hwang, H.S.; Kim, E.C.; Kim, M.S. Novel Tear Interferometer Made of Paper for Lipid Layer Evaluation. Cornea 2014, 33, 826-831. [CrossRef]

70. Goto, E.; Tseng, S.C.G. Kinetic analysis of tear interference images in aqueous tear deficiency dry eye before and after punctal occlusion. Investig. Opthalmol. Vis. Sci. 2003, 44, 1897-1905. [CrossRef]

71. Eom, Y.; Lee, J.-S.; Kang, S.-Y.; Kim, H.M.; Song, J.-S. Correlation Between Quantitative Measurements of Tear Film Lipid Layer Thickness and Meibomian Gland Loss in Patients With Obstructive Meibomian Gland Dysfunction and Normal Controls. Am. J. Ophthalmol. 2013, 155, 1104-1110.e2. [CrossRef] [PubMed]

72. Cho, B.-J.; Jee, D.H.; Kim, W.J.; Shin, M.C.; Kim, E.C.; Kim, M.S.; Hwang, H.S. Direct Visualization of Continuous Meibum Secretion From the Orifices of Meibomian Glands to the Tear Film. Cornea 2019, 38, 1245-1252. [CrossRef]

73. Molina-Solana, P.; Domínguez-Serrano, F.D.B.; Garrido-Hermosilla, A.M.; Montero-Iruzubieta, J.; Fernández-Palacín, A.; Rodríguez-De-La-Rúa-Franch, E.; Caro-Magdaleno, M. Improved Tear Film Stability in Patients with Dry Eye After Hyaluronic Acid and Galactoxyloglucan Use. Clin. Ophthalmol. 2020, 14, 1153-1159. [CrossRef] [PubMed]

74. Lee, J.M.; Jeon, Y.J.; Kim, K.Y.; Hwang, K.-Y.; Kwon, Y.-A.; Koh, K. Ocular surface analysis: A comparison between the LipiView ${ }^{\circledR}$ II and IDRA ${ }^{\circledR}$. Eur. J. Ophthalmol. 2020. [CrossRef] [PubMed]

75. Giannaccare, G.; Vigo, L.; Pellegrini, M.; Sebastiani, S.; Carones, F. Ocular Surface Workup With Automated Noninvasive Measurements for the Diagnosis of Meibomian Gland Dysfunction. Cornea 2018, 37, 740-745. [CrossRef]

76. Yokoi, N.; Mossa, F.; Tiffany, J.M.; Bron, A.J. Assessment of meibomian gland function in dry eye using meibometry. Arch. Ophthalmol. 1999, 117, 723-729. [CrossRef] [PubMed]

77. Goto, E.; Dogru, M.; Kojima, T.; Tsubota, K. Computer-synthesis of an interference color chart of human tear lipid layer, by a colorimetric approach. Investig. Opthalmol. Vis. Sci. 2003, 44, 4693-4697. [CrossRef]

78. Goto, E. Differentiation of Lipid Tear Deficiency Dry Eye by Kinetic Analysis of Tear Interference Images. Arch. Ophthalmol. 2003, 121, 173-180. [CrossRef]

79. Arita, R.; Yabusaki, K.; Hirono, T.; Yamauchi, T.; Ichihashi, T.; Fukuoka, S.; Morishige, N. Automated Measurement of Tear Meniscus Height with the Kowa DR-1 $\alpha$ Tear Interferometer in Both Healthy Subjects and Dry Eye Patients. Investig. Opthalmol. Vis. Sci. 2019, 60, 2092-2101. [CrossRef]

80. Arita, R.; Morishige, N.; Fujii, T.; Fukuoka, S.; Chung, J.L.; Seo, K.Y.; Itoh, K. Tear Interferometric Patterns Reflect Clinical Tear Dynamics in Dry Eye Patients. Investig. Opthalmol. Vis. Sci. 2016, 57, 3928. [CrossRef]

81. Lee, Y.; Hyon, J.Y.; Jeon, H.S. Characteristics of dry eye patients with thick tear film lipid layers evaluated by a LipiView II interferometer. Graefe's Arch. Clin. Exp. Ophthalmol. 2021, 259, 1235-1241. [CrossRef]

82. Weng, H.-Y.; Ho, W.-T.; Chiu, C.-Y.; Tsai, T.-Y.; Chang, S.-W. Characteristics of tear film lipid layer in young dry eye patients. J. Formos. Med. Assoc. 2021, 120, 1478-1484. [CrossRef] [PubMed]

83. Purslow, C.; Wolffsohn, J. The Relation between Physical Properties of the Anterior Eye and Ocular Surface Temperature. Optom. Vis. Sci. 2007, 84, 197-201. [CrossRef]

84. Craig, J.P.; Singh, I.P.; Tomlinson, A.; Morgan, P.; Efron, N. The role of tear physiology in ocular surface temperature. Eye 2000, 14, 635-641. [CrossRef] [PubMed]

85. Versura, P.; Giannaccare, G.; Fresina, M.; Campos, E.C. Subjective Discomfort Symptoms Are Related to Low Corneal Temperature in Patients with Evaporative Dry Eye. Cornea 2015, 34, 1079-1085. [CrossRef]

86. Morgan, P.; Tullo, A.B.; Efron, N. Infrared thermography of the tear film in dry eye. Eye 1995, 9, 615-618. [CrossRef]

87. Kamao, T.; Yamaguchi, M.; Kawasaki, S.; Mizoue, S.; Shiraishi, A.; Ohashi, Y. Screening for Dry Eye With Newly Developed Ocular Surface Thermographer. Am. J. Ophthalmol. 2011, 151, 782-791.e1. [CrossRef] [PubMed]

88. Su, T.-Y.; Chang, S.-W.; Yang, C.-J.; Chiang, H.K. Direct observation and validation of fluorescein tear film break-up patterns by using a dual thermal-fluorescent imaging system. Biomed. Opt. Express 2014, 5, 2614-2619. [CrossRef]

89. Baudouin, C.; Barton, K.; Cucherat, M.; Traverso, C. The Measurement of Bulbar Hyperemia: Challenges and Pitfalls. Eur. J. Ophthalmol. 2015, 25, 273-279. [CrossRef]

90. Leibowitz, H.M. The Red Eye. N. Engl. J. Med. 2000, 343, 345-351. [CrossRef]

91. Schuman, J.S. Short- and long-term safety of glaucoma drugs. Expert Opin. Drug Saf. 2002, 1, 181-194. [CrossRef]

92. Giannaccare, G.; Pellegrini, M.; Bernabei, F.; Senni, C.; Aloi, M.; Scalzo, G.C.; Ceravolo, D.; Iovino, C.; Scorcia, V. Comparative analysis of ocular redness score evaluated automatically in glaucoma patients under different topical medications. Eur. J. Ophthalmol. 2020. [CrossRef]

93. Giannaccare, G.; Blalock, W.; Fresina, M.; Vagge, A.; Versura, P. Intolerant contact lens wearers exhibit ocular surface impairment despite 3 months wear discontinuation. Graefes Arch. Clin. Exp. Ophthalmol. 2016, 254, 1825-1831. [CrossRef]

94. Vagge, A.; Senni, C.; Bernabei, F.; Pellegrini, M.; Scorcia, V.; E Traverso, C.; Giannaccare, G. Therapeutic Effects of Lactoferrin in Ocular Diseases: From Dry Eye Disease to Infections. Int. J. Mol. Sci. 2020, 21, 6668. [CrossRef] [PubMed]

95. Roda, M.; Corazza, I.; Reggiani, M.L.B.; Pellegrini, M.; Taroni, L.; Giannaccare, G.; Versura, P. Dry Eye Disease and Tear Cytokine Levels-A Meta-Analysis. Int. J. Mol. Sci. 2020, 21, 3111. [CrossRef] 
96. Schulze, M.; Jones, D.; Simpson, T.L. The Development of Validated Bulbar Redness Grading Scales. Optom. Vis. Sci. 2007, 84, 976-983. [CrossRef]

97. Park, I.K.; Chun, Y.S.; Kim, K.G.; Yang, H.K.; Hwang, J.-M. New Clinical Grading Scales and Objective Measurement for Conjunctival Injection. Investig. Opthalmol. Vis. Sci. 2013, 54, 5249-5257. [CrossRef] [PubMed]

98. Singh, R.B.; Liu, L.; Anchouche, S.; Yung, A.; Mittal, S.K.; Blanco, T.; Dohlman, T.H.; Yin, J.; Dana, R. Ocular redness-I: Etiology, pathogenesis, and assessment of conjunctival hyperemia. Ocul. Surf. 2021, 21, 134-144. [CrossRef] [PubMed]

99. Villumsen, J.; Ringquist, J.; Alm, A. Image analysis of conjunctival hyperemia. Acta Ophthalmol. 2009, 69, 536-539. [CrossRef]

100. Willingham, F.F.; Cohen, K.L.; Coggins, J.M.; Tripoli, N.K.; Ogle, J.W.; Goldstein, G.M. Automatic quantitative measurement of ocular hyperemia. Curr. Eye Res. 1995, 14, 1101-1108. [CrossRef]

101. Rodriguez, J.D.; Johnston, P.R.; Iii, G.W.O.; Abelson, M.B.; Smith, L.M. Automated grading system for evaluation of ocular redness associated with dry eye. Clin. Ophthalmol. 2013, 7, 1197-1204. [CrossRef]

102. Efron, N.; Morgan, P.B.; Katsara, S.S. Validation of grading scales for contact lens complications. Ophthalmic Physiol. Opt. 2001, 21, 17-29.

103. Wu, S.; Hong, J.; Tian, L.; Cui, X.; Sun, X.; Xu, J. Assessment of Bulbar Redness with a Newly Developed Keratograph. Optom. Vis. Sci. 2015, 92, 892-899. [CrossRef]

104. Roy, N.S.; Wei, Y.; Kuklinski, E.; Asbell, P.A. The Growing Need for Validated Biomarkers and Endpoints for Dry Eye Clinical Research. Investig. Opthalmol. Vis. Sci. 2017, 58, BIO1-BIO19. [CrossRef]

105. Rajalakshmi, R.; Dutt, S.; Sivaraman, A.; Savoy, F. Insights into the growing popularity of artificial intelligence in ophthalmology. Indian J. Ophthalmol. 2020, 68, 1339-1346. [CrossRef]

106. Yedidya, T.; Hartley, R.; Guillon, J.-P.; Kanagasingam, Y. Automatic Dry Eye Detection. In Medical Image Computing and ComputerAssisted Intervention-MICCAI 2007; Springer: Brisbane, Australia, 2007; pp. 792-799.

107. Ramos, L.; Barreira, N.; Mosquera, A.; Currás, M.; Pena-Verdeal, H.; Giráldez, M.J.; Penedo, M.G. Computational Approach for Measuring the Tear Film Break-Up Time in an Unsupervised Manner. Commun. Netw. 2013, 254-267.

108. Krizhevsky, A.; Sutskever, I.; Hinton, G.E. ImageNet classification with deep convolutional neural networks. Adv. Neural Inf. Process. Syst. 2012, 25, 1097-1105. Available online: https:// proceedings.neurips.cc/paper/2012/file/c399862d3b9d6b76c8436e9 24a68c45b-Paper.pdf (accessed on 14 July 2021).

109. Litjens, G.; Kooi, T.; Bejnordi, B.E.; Setio, A.A.A.; Ciompi, F.; Ghafoorian, M.; van der Laak, J.A.; van Ginneken, B.; Sánchez, C.I. A survey on deep learning in medical image analysis. Med. Image Anal. 2017, 42, 60-88. [CrossRef] [PubMed]

110. Su, T.-Y.; Liu, Z.-Y.; Chen, D.-Y. Tear Film Break-Up Time Measurement Using Deep Convolutional Neural Networks for Screening Dry Eye Disease. IEEE Sens. J. 2018, 18, 6857-6862. [CrossRef]

111. Remeseiro, B.; Mosquera, A.; Penedo, M.G.; García-Resúa, C. Tear Film Maps based on the Lipid Interference Patterns. In Proceedings of the International Conference on Agents and Artificial Intelligence, Angers, France, 6-8 March 2014; SCITEPRESS: Setúbal, Portugal, 2014; Volume 1, pp. 732-739.

112. Guillon, J.-P. Non-invasive tearscope plus routine for contact lens fitting. Contact Lens Anterior Eye 1998, 21, S31-S40. [CrossRef]

113. Remeseiro, B.; Barreira, N.; García-Resúa, C.; Lira, M.; Giráldez, M.J.; Yebra-Pimentel, E.; Penedo, M.G. iDEAS: A web-based system for dry eye assessment. Comput. Methods Programs Biomed. 2016, 130, 186-197. [CrossRef] [PubMed]

114. Acharya, U.R.; Tan, J.H.; Koh, J.E.; Sudarshan, V.K.; Yeo, S.; Too, C.L.; Chua, C.K.; Ng, E.; Tong, L. Automated diagnosis of dry eye using infrared thermography images. Infrared Phys. Technol. 2015, 71, 263-271. [CrossRef]

115. Giannaccare, G.; Vaccaro, S.; Mancini, A.; Scorcia, V. Dry eye in the COVID-19 era: How the measures for controlling pandemic might harm ocular surface. Graefe's Arch. Clin. Exp. Ophthalmol. 2020, 258, 2567-2568. [CrossRef] [PubMed] 